\title{
Cowongan is the Cultural Heritage of Banyumas: Relevance of Rituals as a part of the Value Character Education
}

\author{
S F Kamal, K Saddhono, and Suyitno \\ Universitas Sebelas Maret, Surakarta, Indonesia \\ kundharu@uns.ac.id
}

\begin{abstract}
Cowongan rituals have existed since a long time ago (the days of ancestors) and need to be preserved today. This study aims to determine the relevance of cowongan ritual as a part of the value of character education Senior High School in Baturaden. Cowongan comes from the word "cowong" which means that the perok/barongan is used to request the downfall of rain through the cowongan ritual. The problems discussed in this article are related to cowongan background, the values contained in cowongan rituals, and the relevance of these values to character education. The research method used in this study is descriptive qualitative. The researcher collects data through in-depth interviewing, direct observation with passive participation, and documentation. The data analysis technique used to analyze cowongan cultural traditions is a qualitative descriptive technique. The results showed that there was cowongan ritual relevance with the value of character education Senior High School in Baturaden. The values contained in the cowongan tradition are cultural values in the behavior of the cowongan tradition, aesthetic values in the cowongan tradition poetry, aesthetic values in the symbol of cowongan tradition objects, religious values in cowongan tradition lyrics, and social values and religious values of the cowongan tradition of Banyumas Regency positive attitude that can be used as learning for a better life.
\end{abstract}

Keywords: Cultural; Cowongan; Character Education; High School

\section{INTRODUCTION}

Cowongan is one of the ritual ceremonies in Banyumas. A ritual is an activation system or series of actions arranged by custom or law that applies in the community that are related to the types of permanent events that usually occur in the community concerned [1]. Various forms of ceremonies are recognized as activities that refresh the soul, so it needs to be endeavored for sustainability as well as continuous coaching, so that it has become rooted in tradition [2]. Cowongan is a means to express people's desire for rain. The cowongan ritual is carried out by traditional farmers who desperately need the arrival of rain to irrigate rice fields that are a source 
of livelihood. If the dry season is too long the immediate result is suffering caused by drought. The trust of the local community is motivated by the way of thinking of their ancestral cultural heritage. Cultural remains are called animism, dinamism, and totemism [3].

There are two things that are important in implementing cowongan, namely art activities and traditional forms of ritual, which are means of communication between humans and nature which are intended to bring rain, referred to as senior activities because they are related to poems which do not include prayers that are performed in the form song. Irus or Siwur are ceremonial properties equipped with a princess. Prayers addressed to the ruler of nature so that the rain immediately descends. The Banyumas community believes that nymphs will be present in the cowongan property which is a means of ritual. The purpose of the dances in cowongan ritual is the hope of humans to get something, for example fertility, health, life, strength, profit, victory, etc. [4].

Cowongan is usually carried out during every dry season. In Javanese calendar calculations, the dry season starts from the prey of saddha (around May) to the prey of prey (around October). Usually in the Katelu prey (August) agricultural lands have begun to dry up and there is a shortage of groundwater supplies. Drought peaks usually begin in the kapat (September) prey to the kalmia prey (October). If the prey does not rain, the population will suffer from water shortages. The cowongan ritual is usually performed on kapat prey before the kalmia prey, which is around September.

The cowongan property is an attraction for the workman/artist for the different forms of property of cowongan when before being entered into the spirit and trusted by the Banyumas community, spirits or senses have been entered, with the present present such as glaring, smiling, beautiful, sinister, glancing, and looking and fierce. Actually Nini Thowong is not just an ordinary game, but is a ceremony to call rain, treatment, or look for lost items. Thus cowongan can also be interpreted into a form of play [5]. Cowongan rituals have noble values that have relevance to the value of character education. "... character education is a program that can be implemented in order to turn students into respectful, responsible, contributing members of society" [6].

The value of character education in cowongan is found in the implementation of cowongan rituals. Through the school level, the role of character education is the foundation and guideline of the teacher in carrying out learning in the classroom. This is due to current learning prioritizing students' attitudes which are reflected through character education, then emphasizing cognitive or knowledge aspects, psychomotor aspects and skills aspects. Through learning activities conducted in schools, the value of character education found in cowongan rituals can be used as study material in teaching and learning activities. Character education is currently the main goal of learning in schools as a form of developing student attitudes. Based on that, of course the value of character education in cowongan rituals has a relationship that is in harmony with the world of education. Therefore, the focus of this study is the philosophical meaning of Cowongan ritual as a value of character education in schools.

There are several studies that are relevant to the research carried out, namely research related to cowongan performances from the beginning to the end to be enjoyed and seen in them containing elements of beauty value [7]. The results of other studies explain that water is one of the basic needs for living things so that water is often referred to as a source of livelihood [8]. Moreover, for agrarian societies, water is a very vital need, the life and death of agricultural crops, including: very dependent on water, both rainwater and irrigation water. 
The researcher feels that research on cowongan is still very lacking and important to conduct. This is due to the reference mentioned above, no one has clearly discussed the philosophy of cowongan which can clarify and seek the philosophy of the ritual of cowongan in today's modern life and its relevance to character education in schools.

The selection of the focus of this study is based on several things, namely, first, an interesting topic of cowongan ritual, especially on cowongan equipment itself. There have not been studies that examine the cowongan specifically, because the research that has been carried out only discusses the symbolic meaning contained in cowongan. Another thing that is the reason for the researchers to choose the focus of research is about the values of character education contained in cowongan equipment. Explicitly, these things have not been understood by the younger generation now. Therefore, it is necessary to disclose the philosophical meaning and value of character education in cowongan equipment, so that it is understood and understood by the present generation, especially through learning in schools. This is of course directly proportional to learning which prioritizes the value of character education in the school environment.

Based on the description above, the study of philosophical meanings, from cowongan rituals, in which the relevance to character education in high schools is used as the basis for researchers to choose the focus of research. This study is the implementation of cowongan rituals, the values contained in cowongan rituals and their relevance to character education Senior High School in Baturaden. The aim is to observe and identify the philosophical meanings and forms of character education in school.

\section{METHOD}

The form of research used in this study is descriptive qualitative research. The point is by tracing objects to find and interpret the relationships of various elements in them [9]. This research method holds that everything in the form of a sign system does not have to be underestimated, everything is important and has influence, and is related to one another. The approach taken is to use a philosophical, ethnographic and symbolic approach. Ethnography is an approach to learning about the social and cultural life of a community [10]. The ethnographic approach in this study was conducted on Cowongan rituals.

The data used as the object of the research are concerning the relevance of the ceremony of the tradition of the cowongan cultural tradition with the values of character education in Baturaden High School. The data in the form of oral data is used to find out the values contained in cowongan cultural traditions in Banyumas Regency. Data sources in this study include sources of oral data and written data sources. The data sources of this research are interviews and forms of cowongan cultural traditions. Data collection techniques used in this study are indepth interviewing, direct observation with passive participation, and documentation. The data analysis technique used to analyze cowongan cultural traditions is a qualitative descriptive technique.

\section{RESULT AND DISCUSSION}

Cowongan is a means to express the desire of the community for rain. As a traditional farming community, people living in Banyumas certainly need rain to irrigate rice fields that are a source of life. If the dry season is too long, then they will be suffering because of the 
drought. By looking further at the implementation of cowongan, it can be obtained an illustration that in the implementation of cowongan there are 2 important things, namely the activity of art and traditional forms of ritual which become a means of communication between humans and nature which aims to bring rain.

It is referred to as an art activity because in it, there are poems which are nothing but prayers performed in the form of tembang, irus or siwur which are the ceremonial properties which are decorated to resemble a princess. Siwur made from coconut shell is a water shearer that symbolizes a hope for the people of the area to reduce rain [11]. The prayers were addressed to the ruler of nature so that the rain immediately fell. It is referred to as a traditional ritual because there are offerings, properties, rituals and prayers which are all intended as a request to the authorities of all nature to immediately bring rain. The motivation is to carry out the ceremony because humans (the community) respect the existence of spirits who have helped, provided safety and religious satisfaction. Ceremonies as a series of special actions have rules and special means to carry them out [12]. In the cowongan show, there are several important aspects presented as follows:

a. Cowongan shows as a form of Javanese folk games

Cowongan game is a singing game that uses the property irus (doll) as a nini cowong, which in this case is categorized as a magic game or ritual ritual of cowongan. This game is sacred, because it is a program for asking for rain accompanied by performances or cowongan games.

b. Cowongan as a ritual performance

The hallmark of the cowongan performance ritual in the ceremony of asking for rain is reflected in

1) held on Kliwon Friday night

2) the place that is used specifically is the terrace (the front part of the house)

3) the actors are all women who are in a holy state

4) the availability of offerings (sesaji)

c. The cowongan show as a form of ceremony to bring magical power, which is reflected in:

1) the verses of the song sung by the actors of cowongan are prayers (spell).

2) a dukun/traditional helper (cowongan elder) utters a spell accompanied by an act of burning the incense aimed at supernatural powers in order to help smooth the show without any obstacles.

d. Cowongan shows are customary practices carried out by the community during long droughts. Customary habits are carried out from generation to generation which cannot be replaced by anything and is always respected and obeyed.

e. Cowongan shows contain aesthetic aspects. This is reflected in the poetry of the song that is dubbed and the fashion dressing. The presence of cowongan does not depend on the audience as Pariyem said "eventhough there is no spectator, the show is still performed. If it is stopped, then we will get some punishment from the protector" he ceremonial times are usually felt as moments that are precarious and serious and full of occult dangers [13]. 
Teaching and learning in schools currently prioritizes the cultivation of character education to students. Education based on local wisdom is able to give meaning to Indonesian human life. This means that education will then be able to become a spirit that can color the dynamics of Indonesian people in the future [14]. Local wisdom is the capital of the formation of noble characters who always act with full awareness, self-primacy, and self-control [15]. Cowongan as one of the indigenous cultural heritages of Banyumas region also contains character education values. The value of character education is interpreted as pitutur, pitudhuh and piwulang for the community. The value of education can be taken from the core which will be applied to learning in school.

Through one particular basic competency, the value of character education reflected through puppets (irus) can be used as a means and source in teaching and learning activities. This is certainly a means of supporting learning materials and applied in schools. The role and equipment of puppets (irus) in traditional cowongan ceremonies can be used as a means and medium of learning on Javanese language subjects at senior high school level. The lesson that can be taken is mainly regarding the relationship between humans and their Lord, that humans are only beings who are weak before Him. Every act that has been done by every human being, good or bad will be rewarded accordingly. In addition, only to Him they ask forgiveness for everything that has been done [16].

Educational values and meanings contained in puppets (irus) can be evaluated in Javanese language teaching at senior high school level. This has been explained in the Regional Regulation of Central Java Province in 2012 Local Regulation no. 4 of 2012 describes the subject of local content, namely language, literature, and Javanese culture that is taught at all levels of education. These subjects need to apply the noble values of Javanese culture, and the value of character education needs to be instilled in the younger generation through Javanese language teaching and learning at the school level.

This is in line with the results of the study stating that several factors and social capital underlying and supporting student character education in schools. These factors include participation and social relations, trust, social norms, social rules, and proactive behavior. Based on these factors, the characteristics of students can be identified. There are also other elements that support students' character, namely regarding the educational environment in families, schools and communities. These things build character as a bridge to optimally achieve the character education goals and functions [17].

The existence of local culture as a means of supporting learning material in schools has been applied in Senior High School in Baturaden. Sometimes Sri Galuh's mother also deviates from her course and there is some material that is replaced because it already exists in other subjects. This is stated in the following quote.

"Alhamdulillah from the first 2009 teaching here, I tended to teach our own culture, Banyumas. So, yes, to be honest, I have taught it a bit off the curriculum. In the curriculum there are unstandardized sentences, deductive and inductive paragraphs. Because in Bahasa Indonesia subject the material already exists, I replaced it with other material, like Cowongan, I input it and I teach it to students."

Based on the results of interviews that have been conducted, the use of doll equipment (irus) has its own power and strength as an effort to succeed learning for students. This attracts the attention of students and tends to be enthusiastic to get to know culture in the environment of the students themselves. So the role of doll equipment (irus) has the feasibility and suitability 
when applied as one of the Javanese language learning teaching materials at senior high school level. This is in line with the results of research on the influence of Javanese culture on the education curriculum in Indonesia, namely there are four pillars underlying Javanese culture, namely mythos (myths), logos (science), ethos (work methods), and pathos (hidden forces) [18]. Based on these pillars, then it is applied in the educational system.

Education in institutions (various levels) not only transfers knowledge, but also places where attitude, character and leadership grow [19]. This is the basis of Indonesian law and character and means for the younger generation to build character education. According to this, it must be prepared to welcome and as a way to the golden age in 2045. The importance of tradition in the development of a nation's life cannot be denied. The tradition is the root of cultural development that gives a nation's identity or personality [20]. This culture needs to be preserved in future generations so that it does not become extinct. In upright inheritance, parents pass on their skills, beliefs, cultural motives and so on to their children and grandchildren [21].

Banyumas traditional arts can still be enjoyed today because the people still adhere to the noble cultural values of our ancestors. This is reflected in almost all traditional art forms performed by the community. This cowongan folk art is a simple example of how people enjoy it not only as an art, but rather a belief in the myth that brings blessings to them.

Based on the statement above, the teacher at this school has applied materials about cowongan and introduced it well before the research was conducted. Teachers tend to take cultural materials in their surroundings. For example the teacher introduced puppet material, ketoprak, and for Grade XI, semester 2, he taught local culture namely ujungan and begalan Banyumasan. Furthermore, Sri Galuh conveyed that the feasibility of Cowongan was used as a source of character education values and applied in schools to students. The purpose of character education is to improve the quality of the implementation and results of school education that leads to the achievement of the formation of character and noble character of students as a whole, integrated, and balanced according to graduate competency standards [22]. This is appropriate and is in line with the philosophy taught in the equipment of the doll (irus). The teacher realizes that the value of character education is suitable for students at school. This is because character education is the main goal for students as a form of developing student attitudes in school. Based on the teacher's opinion above, it can be concluded that the use of doll tools (irus) has feasibility and suitability when used and applied as a means, learning teaching materials and sources of value for Javanese language character education in senior high school (SMA).

\section{CONCLUSION}

Based on the research conducted by the writer, it can be concluded that the cowongan ritual is carried out by women in a sacred state with cowongan traditional equipment, namely irus or siwur and clothes worn by cowongan traditionists who wear clothes that are used daily (no specific provisions), equipment offerings in the implementation of the cowongan tradition, including: (incense incense, three-color flower, telon flowers: kenanga, roses, and kantil, as well as market snacks, and verses of the cowongan tradition in the form of prayer songs to God in order for the rain to fall immediately. The values contained in cowongan tradition are cultural values in the behavior of cowongan tradition, aesthetic values in the cowongan tradition poetry, aesthetic values in cowongan tradition objects, religious values in cowongan tradition, and social and religious values of cowongan tradition in the Regency Banyumas are positive 
attitudes that can be used as learning for a better life. The values contained in cowongan ritual have relevance to the value of character education in senior High School in Baturaden. So, for some high schools in the Banyumas area, cowongan rituals can be introduced to the students in order to instill the character.

\section{ACKNOWLEDGMENTS}

The researchers express their thanks, appreciation and achievement to Universitas Sebelas Maret Surakarta and the committee of UP-INCASE 2018 conference so this research can be published.

\section{REFERENCES}

[1] Koentjaraningrat, Kebudayaan, Mentalitas dan Pembangunan. Jakarta: Gramedia Pustaka Utama, 1994.

[2] H. K. Bayu, "Perubahan Masyarakat dan Kebudayaan Terhadap Tradisi Kesenian Tiban," J. Univertas Airlangga, vol. 3, no. 1, pp. 1-11, 2014.

[3] S. Ben, Tayub: Pertunjukan dan Ritus Kesuburan. Bandung: MSPI dan Artline, 1999.

[4] Soedarsono, Seni Pertunjukan Indonesia di Era Globalisasi. Yogyakarta: Depdikud, 1998.

[5] D. Sukirman, Permainan Tradisional Jawa. Yogyakarta: Kepel Press, 2004.

[6] Creasy, "What is Character Education?," J. Educ. Policy, vol. 3, no. 12, pp. 172-180, 2008.

[7] L. Umi, "Bentuk Pertunjukkan Tari Cowongan Padhepokan Seni Cowong Sewu dalam Ritual Minta Hujan Desa Pangebatan Kecamatan Karanglewas Kabupaten Banyumas," Universitas Muhammadiyah Purwokerto, 2013.

[8] A. Christriyani, "Cowongan: Seni Tradisi Pemanggil Hujan Masyarakat Banyumas Jawa Tengah,” PATRAWIDYA Seri Pnb. Penelit. Sej. Dan Budaya, vol. 12, no. 3, pp. 777-809, 2012.

[9] H. B. Sutopo, Metodologi Penelitian Kualitatif. Surakarta: Universitas Sebeleas Maret Press, 2006.

[10] S. Imam, "Etnografi dan Genre Sastra Realisme Sosialis," Asintya J. Penelit. Seni Budaya, vol. 1, no. 2, pp. 109-118, 2009.

[11] Lina M H, "Cingcowong: Upacara Ritual Meminta Hujan di Desa Luragung Landeuh Kecamatan Luragung Kabupaten Kuningan,” J. Ekspresi Seni, vol. 17, no. 2, pp. 230$243,2015$.

[12] K. Hermin, Makna Tari Dalam Upacara di Indonesia. Yogyakarta: ISI Yogyakarta, 1990.

[13] S. Emon, Paririmbon Sunda. Bandung: Departemen Pendidikan dan Kebudayaan Propinsi Jawa Barat, 1992.

[14] N. I. Fitri, "Pendidikan Karakter Berbasis Nilai-Nilai Kearifan Lokal Adat Ammatoa dalam Menumbuhkan Karakter Konservasi,” J. Cendekia, vol. 10, no. 1, pp. 1-18, 2016.

[15] Wagiran, "Pengembangan Karakter Berbasis Kearifan Lokal Hamemayu Hayuning Bawana (Identifikasi Nilai-nilai Karakter Berbasis Budaya)," J. Pendidik. Karakter, vol. 2, no. 3, 2012.

[16] Ilham H, “Tradisi Minta Hujan Armarohimin," J. Ilmu Sos. dan Hum., vol. 2, no. 1, pp. $11-24,2011$.

[17] Dwiningrum and Astuti, "Nation's Character Education Based on the Social Capital 
Theory," Asian Soc. Sci., vol. 9, no. 12, 2013.

[18] T. Sahid, "The Influence of Javanese Culture on the Education Curriculum in Indonesia," J. Educ. Pract., vol. 4, no. 19, pp. 139-142, 2013.

[19] F. Rokhman, M. Hum, A. Syaifudin, and Yuliati, "Character Education for Golden Generation 2045 (National Character Building for Indonesian Golden Years)," Procedia - Soc. Behav. Sci., vol. 141, no. 141, pp. 1161-1165, Aug. 2014.

[20] Sal Murgiyanto, Tradisi dan Inovasi. Jakarta: Wedatama Widyasastra, 2004.

[21] John W B, Psikologi Lintas Budaya: Riset dan Aplikasi. Jakarta: Penerbit Gramedia Pustaka Utama, 1999.

[22] S. Suparlan, Filsafat Pendidikan. Yogyakarta: Ar-Ruzz Media, 2008. 